\title{
Analisis Dampak Pemekaran Daerah Terhadap Kinerja Keuangan dan Pelayanan Publik
}

\author{
Endah Trikurniasih, Rahmi Handayani, Agus Santoso, Ahmad Soleh \\ Universitas Muhammadiyah Jambi, Indonesia \\ Correspondence email: mas.soleh@yahoo.com
}

\begin{abstract}
Decentralization is a tool to achieve one of the objectives of the state, especially providing public services. Decentralization is often called granting autonomy. The formation of autonomous regions, including through regional expansion. During the 16 years of the decentralization era, the rate of increase in DOB was very fast. In addition to the growth of new autonomous regions, transfers of central revenue to regions have also increased. Following the national phenomenon, the implementation of decentralization in Jambi Province was also marked by regional expansion. Jambi Province is one of the provinces that has significantly expanded regions. Regional expansion is deemed necessary given the development of the population and the increasing workload and work volume in each district. On that basis, I would like to carry out research related to the impact of pemekaran on financial performance and public services. This study aims to analyze the impact of regional expansion in Jambi Province on parent regions and new autonomous regions in terms of regional and public financial aspects in the post-division period. Analysis of the data in this study used qualitative and quantitative descriptive analysis. The results showed that regional expansion had a positive impact on financial performance and public services.
\end{abstract}

Keywords: Regional Expansion; Financial Performance; Public Service Performance

\section{PENDAHULUAN}

Desentralisasi merupakan sebuah alat untuk mencapai salah satu tujuan bernegara terutama memberikan pelayanan publik. Desentralisasi sering disebut pemberian otonomi. Pembentukan daerah otonomi, diantaranya melalui pemekaran daerah. Selama 16 tahun era desentralisasi, laju pertambahan DOB amat cepat. Selain pertumbuhan DOB, transfer penerimaan pusat ke daerah jug amengalami peningkatan. Mengikuti fenomena yang terjadi secara nasional, implementasi desentralisasi di Provinsi Jambi juga ditandai dengan pemekaran daerah. Provinsi Jambi merupakan salah satu provinsi yang melakukan pemekaran daerah dengan cukup signifikan. Seluruh daerah kabupaten di Provinsi Jambi telah dimekarkan, sehingga kabupaten/kota yang sebelumnya hanya berjumlah 6 kabupaten/kota telah berkembang menjadi 11 kabupaten/kota. Pemekaran daerah dirasa perlu mengingat perkembangan jumlah penduduk dan meningkatnya beban tugas serta volume kerja di masing-masing kabupaten.

Selama lebih dari satu dasawarsa pemekaran daerah di Kabupaten se Provinsi Jambi, tingkat pelayanan publik di Provinsi Jambi masih terbilang buruk. Dari penilaian Ombudsman, 60\% pelayanan yang diberikan SKPD dan di pemerintah daerah maupun instansi vertikal masih mendapatkan rapor merah dan jauh dari kenyataan yang kita harapkan (sr28jambinews, 17 April 2014). Dari sisi pembangunan, pertumbuhan ekonomi Provinsi Jambi pada triwulan I tahun 2014 tercatat tertinggi di Sumatera dan kedua tertinggi dibandingkan seluruh provinsi di Indonesia. Pertumbuhan ekonomi Provinsi Jambi tumbuh sebesar $8,37 \%$ pertahun, meningkat dibandingkan triwulan sebelumnya $(6,93 \%)$ serta lebih tinggi dibandingkan pertumbuhan ekonomi nasional (5,53 \%) dan Sumatera (5,43 \%) (Republika, 29 Mei 2014). Namun hasil analisis kinerja keuangan terhadap kabupaten/kota pemekaran di Provinsi Jambi tidak jauh berbeda dengan kabupaten/kota pemekaran lainnya di Indonesia. Rata-rata rasio PAD terhadap APBD Kabupaten/Kota di Provinsi Jambi periode tahun 2007 - 2011 adalah 6,33\%. Berdasarkan hal tersebut, penelitian ini bertujuan untuk menganalisis dampak pemekaran daerah di Provinsi Jambi terhadap daerah induk dan daerah otonomi baru ditinjau dari aspek keuangan daerah dan pelayanan publik pada periode sesudah pemekaran.

\section{METODE}

Data yang digunakan adalah data kuantitatif yang diperoleh dari DJPKPD dan BPS. Data dikumpulkan dengan menggunakan teknik Library Reasearh, yaitu yang berhubungan dengan masalah penelitian. Daerah penelitian adalah sebagai berikut: 
Tabel 1

Daerah peneilitian

\begin{tabular}{llll}
\hline No & Daerah Induk & DOB & UU Pembentukan \\
\hline 1 & Merangin & Sarolangun & UU No. 54 Th 1999 \\
2 & Bungo & Tebo & UU No. 54 Th 1999 \\
3 & Batang Hari & Muaro Jambi & UU No. 54 Th 1999 \\
4 & Tanjung Jabung Barat & Tanjung Jabung Timur & UU No. 54 Th 1999 \\
5 & Kerinci & Sungai Penuh & UU No. 25 Th 2008 \\
\hline
\end{tabular}

Sumber: data primer

\section{Analisis Data}

Metode analisis data menggunakan analisis deksriptif dan analisis uji beda dua rata-rata independen. Analisis deskriptif dimulai dengan perhitungan rasio untuk memperoleh nilai dari indikator -indikator pada aspek keuangan daerah dan aspek pelayanan publik. Kemudian penulis mendeskripsikan rata-rata perkembangan dan pertumbuhan dari indikator-indikator tersebut. Teknik analisis uji beda dua rata-rata sampel independen untuk mengetahui perkembangan indikator-indikator pada aspek keuangan daerah dan pelayanan publik yang dianalisis pada daerah induk dan daerah otonomi baru memiliki perbedaan yang bermakna. Sebagai kerangka acuan untuk mendeskripsikan masalah yang diungkap. Setiap aspek yang dievaluasi akan diwakili oleh beberapa indikator. Adapun indikator serta perhitungannya dapat dijelaskan sebagai berikut:

1. Kinerja keuangan pemerintah daerah

a. Ketergantungan fiskal $(\mathrm{KF})$

$$
\text { Ketergantungan Fiskal }=\frac{\text { Dana Alokasi Umum }- \text { Belanja Pegawai }}{\text { Total Pendapatan Daerah }} \times 100 \%
$$

b. Kapasitas penciptaan pendapatan (KPP)

$$
\text { Kapasitas Penciptaa Pendapatan }=\frac{\text { Pendapatan Asli Daerah }}{\text { Produk Domestik Regional Bruto }} \times 100 \%
$$

c. Proporsi belanja modal (BM)

$$
\text { Proporsi Belanja Modal }=\frac{\text { Belanja Modal }}{\text { Belanja Daerah }} \times 100 \%
$$

d. Kontribusi sektor pemerintah (KSP)

$$
\text { Kontribusi Sektor Pemerintah }=\frac{\text { Belanja Daerah }}{\text { Produk Domestik Regional Bruto }} \times 100 \%
$$

2. Kinerja pelayanan publik

a. Jumlah siswa per sekolah

$$
\text { Rasio Siswa Per Sekolah }=\frac{\text { Jumlah Siswa }}{\text { Jumlah Sekolah }} \times 10.000
$$

b. Jumlah siswa per guru

$$
\text { Rasio Siswa Per Guru }=\frac{\text { Jumlah Siswa }}{\text { Jumlah Guru }} \times 10.000
$$

c. Ketersediaan fasilitas kesehatan

$$
\text { Rasio Faskes per Satuan Penduduk }=\frac{\text { Jumlah Fasilitas Kesehatan }}{\text { Jumlah Penduduk }} \times 10.000
$$

d. Ketersediaan tenaga kesehatan

$$
\text { Rasio Tenaga Kesehatan per Satuan Penduduk }=\frac{\text { Jumlah Tenaga Kesehatan }}{\text { Jumlah Penduduk }} \times 10.000
$$

e. Kualitas infrastruktur

$$
\text { Proporsi Jalan Dalam Kondisi Baik }=\frac{\text { Panjang Jalan dalam Kondisi Baik }}{\text { Total Panjang Jalan }} \times 100 \%
$$




\section{HASIL DAN PEMBAHASAN}

\section{Analisis Kinerja Kuangan Daerah.}

Dalam mengukur kinerja keuangan daerah dalam penelitian ini menggunakan empat indikator yaitu:

a. Tingkat Ketergantungan Fiskal

Hasil analisis menunjukkan tingkat ketergantungan fiskal daerah induk mengalami penurunan lebih dari 10 persen pada tahun 2014 dibandingkan pada tahun 2005. Demikian juga yang terjadi pada daerah otonomi baru dimana pada tahun 2014 tingkat ketergantungan fiskal menurun menjadi 11,9 persen dari 24 persen pada tahun 2005 . Untuk lebih jelasnya dapat dilihat pada tabel dibawah ini.

Tabel 2

Ketergantungan Fiskal Di Daerah Induk Dan DOB

\begin{tabular}{|c|c|c|c|c|c|c|c|c|c|c|c|}
\hline Daerah & 2005 & 2006 & 2007 & 2008 & 2009 & 2010 & 2011 & 2012 & 2013 & 2014 & Rerata \\
\hline Daerah Induk & $20,9 \%$ & $27,2 \%$ & $23,4 \%$ & $14,2 \%$ & $7,4 \%$ & $0,3 \%$ & $1,0 \%$ & $4,8 \%$ & $8,0 \%$ & $7,7 \%$ & $11,5 \%$ \\
\hline DOB & $24,0 \%$ & $31,8 \%$ & $24,9 \%$ & $21,5 \%$ & $11,6 \%$ & $8,5 \%$ & $7,1 \%$ & $10,6 \%$ & $12,5 \%$ & $11,9 \%$ & $16,4 \%$ \\
\hline
\end{tabular}

Sumber: data olahan

b. Kapasitas Penciptaan Pendapatan

Tabel 3.

Kapasitas Penciptaan Pendapatan di Daerah Induk dan DOB

\begin{tabular}{llllllllllll}
\hline Daerah & 2005 & 2006 & 2007 & 2008 & 2009 & 2010 & 2011 & 2012 & 2013 & 2014 & Rerata \\
\hline Daerah Induk & $1,7 \%$ & $1,7 \%$ & $2,1 \%$ & $3,0 \%$ & $2,2 \%$ & $2,3 \%$ & $3,1 \%$ & $2,8 \%$ & $3,6 \%$ & $3,5 \%$ & $2,6 \%$ \\
DOB & $1,1 \%$ & $1,2 \%$ & $1,5 \%$ & $1,8 \%$ & $1,5 \%$ & $1,6 \%$ & $2,3 \%$ & $2,6 \%$ & $2,9 \%$ & $3,1 \%$ & $2,0 \%$ \\
\hline
\end{tabular}

Sumber: data olahan

Pada tabel diatas menunjukkan bahwa terdapat peningkatan kapasitas pendapatan yang cukup signifikan terhadap daerah induk dan derah otonomi baru. Dimana secara rata rata selama 10 tahun daerah induk mampu meningkat sebesar 2,6 persen sementara daerah otonomi baru hanya mampu meningkat sebesar 2 perssen.

c. Proporsi Belanja Modal berikut:

Selanjutnya pada proporsi belanja modal pada daerah induk dan daerah otonom adalah sebagai

Tabel 4

Proporsi Belanja Modal di Daerah Induk dan DOB

\begin{tabular}{cccccccccccc}
\hline Daerah & 2005 & 2006 & 2007 & 2008 & 2009 & 2010 & 2011 & 2012 & 2013 & 2014 & Rerata \\
\hline Daerah Induk & $22,5 \%$ & $28,8 \%$ & $37,4 \%$ & $33,5 \%$ & $27,2 \%$ & $22,6 \%$ & $23,8 \%$ & $25,3 \%$ & $28,9 \%$ & $27,3 \%$ & $27,7 \%$ \\
DOB & $38,4 \%$ & $38,7 \%$ & $45,3 \%$ & $44,6 \%$ & $33,1 \%$ & $30,7 \%$ & $32,0 \%$ & $33,1 \%$ & $35,8 \%$ & $32,9 \%$ & $36,4 \%$ \\
\hline
\end{tabular}

Sumber: data olahan

Secara rata-rata pertumbuhan proporsi belanja modal pada daerah induk berada di atas DOB, kecuali pada tahun 2008-2010. Meskipun rata-rata proporsi belanja modal DOB berada di atas daerah induk, namun rata-rata pertumbuhan proporsi belanja modal di daerah induk sebesar $7 \%$ lebih tinggi dari DOB yang hanya sebesar $2,1 \%$.

d. Kontribusi Sektor Pemerintah di Daerah Induk dan Daerah otonomi Baru

Hasil analisis data diperoleh hasil besarnya kontribusi sektor pada pemerintah pada daerah induk dan daerah otonom adalah sebagai berikut:

Tabel 5

Kontribusi Sektor Pemerintah Di Daerah Induk dan DOB

\begin{tabular}{|c|c|c|c|c|c|c|c|c|c|c|c|}
\hline Daerah & 2005 & 2006 & 2007 & 2008 & 2009 & 2010 & 2011 & 2012 & 2013 & 2014 & Rerata \\
\hline Daerah Induk & $21,9 \%$ & $31,1 \%$ & $37,3 \%$ & $48,9 \%$ & $44,0 \%$ & $43,0 \%$ & $49,5 \%$ & $51,6 \%$ & $55,8 \%$ & $58,2 \%$ & $44,1 \%$ \\
\hline DOB & $31,5 \%$ & $36,9 \%$ & $45,8 \%$ & $56,2 \%$ & $46,4 \%$ & $52,8 \%$ & $56,2 \%$ & $61,6 \%$ & $67,5 \%$ & $53,8 \%$ & $50,9 \%$ \\
\hline
\end{tabular}

Sumber: data olahan 
Secara rata-rata pertumbuhan kontribusi sektor pemerintah pada daerah induk lebih tinggi dari DOB kecuali pada tahun 2007, 2009, 2010 dan 2012. Meskipun kontribusi sektor pemerintah di DOB lebih tinggi dari daerah induk, rata-rata pertumbuhan kontribusi sektor pemerintah di daerah induk sebesar 13,2\% lebih tinggi dari DOB yaitu hanya sebesar 12,7\%

\section{Analisis Kinerja Pelayanan Publik} adalah:

Untuk melihat kinerja pelayanan publik dalam peelitian ini digunakan tiga indikator diantaranya

\section{Dalam Bidang Pendidikan}

Untuk menganalisis kinerja pelayanan publik pada penelitian ini dilihat dari:

a. Rasio Siswa Per sekolah

Berdasarkan data yang ada diperoleh gambaran besarnya rasio siswa persekolah pada daerah induk dan DOB. Secara umum dari tingkat PAUD, Pendidikan Dasar dan Pendidikan Menengah rasio siswa persekolah mengalami peningkatan sedangkan pada daerah otonomi baru mengalami penurunan dibandingkan rata rata rasio sswa perekolah sebelum pemasaran. untuk lebih jelasnya dapat dilihat pada tabel dibawah ini.

Tabel 6

Rasio Siswa per Sekolah di Daerah Induk dan DOB

\begin{tabular}{|c|c|c|c|c|c|c|c|c|c|c|c|c|}
\hline No & Jenjang Pendidikan & 2005 & 2006 & 2007 & 2008 & 2009 & 2010 & 2011 & 2012 & 2013 & 2014 & Rerata \\
\hline \multirow[t]{4}{*}{ I } & PAUD & & & & & & & & & & & \\
\hline & Daerah Induk & 126 & 39 & 40 & 41 & 36 & 57 & 39 & 39 & 41 & 45 & 50 \\
\hline & DOB & 33 & 33 & 30 & 33 & 34 & 36 & 37 & 38 & 45 & 43 & 36 \\
\hline & Rata-Rata I & 79 & 36 & 35 & 37 & 35 & 47 & 38 & 38 & 43 & 44 & 43 \\
\hline \multirow[t]{4}{*}{ II } & Pendidikan Dasar & & & & & & & & & & & \\
\hline & Daerah Induk & 164 & 171 & 163 & 167 & 168 & 164 & 167 & 165 & 159 & 158 & 165 \\
\hline & DOB & 168 & 170 & 159 & 153 & 170 & 163 & 162 & 171 & 166 & 160 & 164 \\
\hline & Rata-Rata II & 166 & 171 & 161 & 160 & 169 & 163 & 165 & 168 & 163 & 159 & 164 \\
\hline \multirow[t]{4}{*}{ III } & Pendidikan Menengah & & & & & & & & & & & \\
\hline & Daerah Induk & 324 & 354 & 349 & 300 & 325 & 392 & 353 & 345 & 335 & 354 & 343 \\
\hline & DOB & 303 & 308 & 290 & 259 & 299 & 328 & 344 & 333 & 317 & 333 & 311 \\
\hline & Rata-Rata III & 313 & 331 & 320 & 280 & 312 & 360 & 349 & 339 & 326 & 343 & 327 \\
\hline
\end{tabular}

Sumber: data olahan

\section{b. Rasio Siswa Per Guru}

Demikian juga yang terjadi pada rasio guru persiswa dimana dengan adanya pemekaran secara rata rata jumlah rasio siswa perguru pada daerah induk juga mengalami peningkatan dibandngkan sebelum dilakukan pemekaran sementara pada daerah otonomi baru justru mengalami penurunan dibandingkan sebelum dilakukan pemekaran. Seperti yang terpapar pada tabel dibawah ini:

Tabel 7

Rasio Siswa per Guru di Daerah Induk dan DOB

\begin{tabular}{|c|c|c|c|c|c|c|c|c|c|c|c|c|}
\hline No & Jenjang Pendidikan & 2005 & 2006 & 2007 & 2008 & 2009 & 2010 & 2011 & 2012 & 2013 & 2014 & Re rata \\
\hline \multirow[t]{4}{*}{ I } & PAUD & & & & & & & & & & & \\
\hline & Daerah Induk & 15 & 11 & 11 & 10 & 10 & 16 & 9 & 9 & 12 & 11 & 11 \\
\hline & DOB & 16 & 12 & 13 & 10 & 10 & 13 & 10 & 10 & 12 & 10 & 12 \\
\hline & Rata-Rata I & 15 & 12 & 12 & 10 & 10 & 14 & 10 & 10 & 12 & 10 & 12 \\
\hline \multirow[t]{4}{*}{ II } & Pendidikan Dasar & & & & & & & & & & & \\
\hline & Daerah Induk & 17 & 20 & 15 & 14 & 13 & 13 & 14 & 14 & 14 & 14 & 15 \\
\hline & DOB & 18 & 20 & 16 & 14 & 14 & 13 & 14 & 14 & 14 & 13 & 15 \\
\hline & Rata-Rata II & 18 & 20 & 16 & 14 & 13 & 13 & 14 & 14 & 14 & 14 & 15 \\
\hline \multirow{5}{*}{ III } & Pendidikan & & & & & & & & & & & \\
\hline & Menengah & & & & & & & & & & & \\
\hline & Daerah Induk & 16 & 21 & 16 & 13 & 14 & 17 & 16 & 14 & 16 & 16 & 16 \\
\hline & DOB & 17 & 18 & 14 & 13 & 13 & 14 & 14 & 12 & 14 & 13 & 14 \\
\hline & Rata-Rata III & 16 & 19 & 15 & 13 & 13 & 15 & 15 & 13 & 15 & 14 & 15 \\
\hline
\end{tabular}

Sumber: data olahan 


\section{Pelayanan Publik Bidang Kesehatan}

Untuk menganalisis kinerja pelayanan publik pada penelitian ini dilihat dari:

a. Fasilitas Kesehatan per 10.000 Penduduk

Dlihat dari fasilitas kesehatannya per 10.000 penduduk secara rata-rata rasio fasilitas kesehatan mengalami peningkatan dibandingkan sebelum adanya pemekaran sementara pada daerah otonomi baru justru mengalami penurunan. Hal ini dapat dilihat pada tabel dibawah ini:

Tabel 8

Rasio Faskes Per 10.000 Penduduk Di Daerah Induk Dan DOB

\begin{tabular}{ccccccccccccc}
\hline Daerah & $\mathbf{2 0 0 5}$ & $\mathbf{2 0 0 6}$ & $\mathbf{2 0 0 7}$ & $\mathbf{2 0 0 8}$ & $\mathbf{2 0 0 9}$ & $\mathbf{2 0 1 0}$ & $\mathbf{2 0 1 1}$ & $\mathbf{2 0 1 2}$ & $\mathbf{2 0 1 3}$ & $\mathbf{2 0 1 4}$ & Rerata \\
\hline Daerah Induk & 3,1 & 3,1 & 3,1 & 3,1 & 3,2 & 2,9 & 2,8 & 2,8 & 2,8 & 2,8 & 2,98 \\
DOB & 2,9 & 2,9 & 2,8 & 3,0 & 2,6 & 2,3 & 2,5 & 2,5 & 2,4 & 2,4 & 2,62 \\
\hline
\end{tabular}

Sumber: data olahan

b. Rasio Tenaga Kesehtan per 10.000 Penduduk

Demikian juga yang terjadi untuk rasio tenaga kesehatan per 10.000 penduduk dimana dengan adanya pemekaran mengalami peningkatan pada daerah induk sementara pada daerah otonomi baru mengalami penurunan di bandingkan sebelum adanya pemekaran.

Tabel 9

Rasio Tenaga Kesehatan Per 10.000 Penduduk

\begin{tabular}{cccccccccccc}
\hline Daerah & $\mathbf{2 0 0 5}$ & $\mathbf{2 0 0 6}$ & $\mathbf{2 0 0 7}$ & $\mathbf{2 0 0 8}$ & $\mathbf{2 0 0 9}$ & $\mathbf{2 0 1 0}$ & $\mathbf{2 0 1 1}$ & $\mathbf{2 0 1 2}$ & $\mathbf{2 0 1 3}$ & $\mathbf{2 0 1 4}$ & Rerata \\
\hline Daerah Induk & 10,4 & 12,9 & 13,2 & 12,8 & 20,7 & 19,7 & 21,9 & 17,5 & 19,9 & 19,7 & 16,9 \\
DOB & 10,0 & 10,6 & 13,9 & 14,7 & 16,6 & 18,4 & 18,3 & 18,2 & 22,6 & 23,5 & 16,7 \\
\hline
\end{tabular}

Sumber: data olahan

\section{Dalam Bidang Infrastruktur Jalan}

Dilihat dari sisi infrastruktur yang dalam hal ini menggunakan data rasio panjang jalan dengan kondisi baik. Pada tabel dibawah memperlihatkan rasio panjang jalan dalam kondisi baik yang secara rata rata kurang dari 50 persen dari jumlah total jalan yang ada.

Tabel 10

Panjang Jalan Kondisi Baik Dengan Total Panjang Jalan

\begin{tabular}{|c|c|c|c|c|c|c|c|c|c|c|c|c|}
\hline No & Uraian & 2005 & 2006 & 2007 & 2008 & 2009 & 2010 & 2011 & 2012 & 2013 & 2014 & Rerata \\
\hline \multicolumn{13}{|c|}{ Panjang Jalan } \\
\hline 1 & Kondisi Baik & 246 & 281 & 301 & 465 & 374 & 315 & 337 & 400 & 501 & 399 & 362 \\
\hline 2 & Total & 979 & 988 & 1.043 & 1.079 & 1.074 & 1.002 & 1.115 & 1.003 & 1.050 & 1.081 & 1.041 \\
\hline \multicolumn{13}{|c|}{ Rasio } \\
\hline 3 & $\begin{array}{l}\text { Kondisi Baik } \\
\text { / Total }\end{array}$ & $25 \%$ & $28 \%$ & $29 \%$ & $43 \%$ & $35 \%$ & $31 \%$ & $30 \%$ & $40 \%$ & $48 \%$ & $37 \%$ & $35 \%$ \\
\hline
\end{tabular}

Sumber: data olahan

Sementara jika dibandingkan rata-rata pertumbuhan rasio panjang jalan kondisi baik dengan total panjang jalan di daerah induk berada di atas DOB kecuali pada tahun 2006-2009 dan 2014. Selama 10 tahun rata-rata pertumbuhan rasio panjang jalan kondisi baik dengan total panjang jalan di daerah induk sebesar $6,9 \%$ lebih rendah dari DOB yaitu sebesar $14,8 \%$. Seperti pada gambar dibawah ini : 


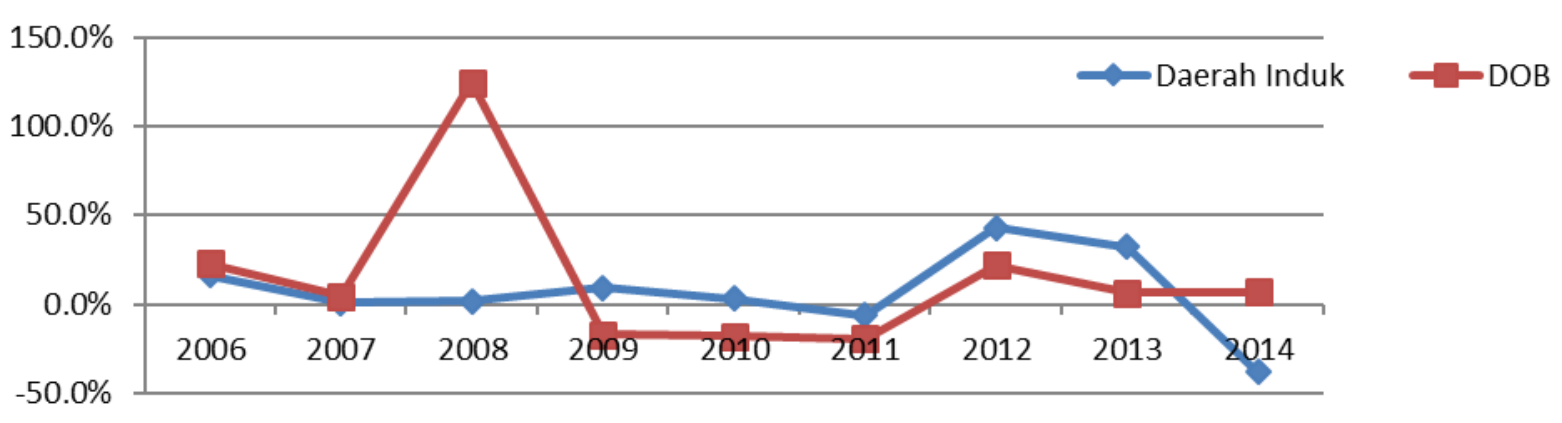

Sumber: data olahan

Gambar 1

Pertumbuhan Proporsi Jalan Dalam Kondisi Baik

\section{Pengujian Hipotesis}

Pengujian hipotesis penelitian menggunakan analisis non parametrik, yaitu mann-whitney $u$ test adalah sebagai berikut:

Tabel 11

Uji hipotesis menggunakan Mann-Whitney U Test

\begin{tabular}{|c|c|c|c|c|c|c|c|}
\hline & KF & KPP & BM & KSP & Faskes & Nakes & SPS_Paud \\
\hline Mann-Whitney & 883,000 & 894,500 & 578,000 & 824,000 & 766,000 & 1136,000 & 756,500 \\
\hline $\mathrm{Z}$ & $-1,961$ & $-1,962$ & $-4,195$ & $-2,391$ & $-2,839$ &,- 103 & $-2,890$ \\
\hline $\begin{array}{l}\text { Mean rank Daerah } \\
\text { Induk }\end{array}$ & 43,16 & 53,61 & 37,06 & 41,98 & 56,18 & 48,22 & 56,37 \\
\hline Mean Rank DOB & 54,30 & 42,95 & 60,93 & 55,59 & 40,15 & 48,80 & 39,95 \\
\hline $\begin{array}{l}\text { Asymptotic } \\
\text { Significane }\end{array}$ &, 050 & 050 & ,000 & ,017 &, 005 & ,918 &, 004 \\
\hline & $\underset{\text { Dasar }}{\text { SPS }}$ & $\begin{array}{r}\text { SPS }_{-} \\
\text {Menegah }\end{array}$ & $\begin{array}{l}\text { SPG_- }_{\text {Paud }} \\
\text { Pas }\end{array}$ & $\begin{array}{r}\text { SPG_ } \\
\text { Dsar }\end{array}$ & $\begin{array}{r}\text { SPG_- } \\
\text { Menengah }\end{array}$ & Jalan & \\
\hline Mann-Whitney & 1143,500 & 549,000 & 1143,000 & 1135,500 & 577,000 & 1040,500 & \\
\hline $\mathrm{Z}$ &,- 048 & $-4,408$ &,- 052 &,- 107 & $-4,228$ &,- 289 & \\
\hline $\begin{array}{l}\text { Mean rank Daerah } \\
\text { Induk }\end{array}$ & 48,63 & 60,52 & 48,36 & 48,79 & 59,96 & 46,23 & \\
\hline Mean Rank DOB & 48,36 & 35,43 & 48,65 & 48,18 & 36,04 & 47,85 & \\
\hline $\begin{array}{l}\text { Asymptotic } \\
\text { Significane }\end{array}$ & ,962 & ,000 & ,959 & ,915 &, 000 &, 773 & \\
\hline
\end{tabular}

Sumber: data olahan

Hasil uji statistik menunjukkan bahwa nilai signifikansi pada variabel-variabel BM $(0,000)$, KSP $(0,017)$, Faskes $(0,05)$, SPS_Paud $(0,004)$, SPS_Menegah $(0,000)$ dan SPG_Menengah $(0,000)$ lebih kecil dari 0,05. Dengan demikian kinerja daerah induk dan DOB yang diukur dengan keenam variabel tersebut memiliki perbedaan yang signifikan, sedangkan kinerja kinerja daerah induk dan DOB yang diukur dengan variabel KF, KPP, Nakes, SPS_Dasar, SPG_Paud, SPG_Dasar dan Jalan memiliki perbedaan namun tidak signifikan.

\section{SIMPULAN}

Dari hasil ini maka dapat diperoleh beberapa kesimpulan sebagai berikut:

1. Pemekaran daerah berdampak terhadap penurunan ketergantungan fiskal di daerah induk dan DOB. Kondisi ketergantungan fiskal di daerah induk lebih baik dari DOB.

2. Pemekaran daerah berdampak terhadap peningkatan kapasitas penciptaan pendapatan di daerah induk dan DOB. Kondisi kapasitas penciptaan pendapatan di daerah induk lebih baik dari DOB.

3. Pemekaran daerah berdampak terhadap peningkatan proporsi belanja modal di daerah induk dan DOB. Kondisi proporsi belanja modal di DOB lebih baik dari daerah induk.

4. Pemekaran daerah berdampak terhadap peningkatan kontribusi sektor pemerintah di daerah induk dan DOB. Kondisi kontribusi sektor pemerintah di daerah induk lebih baik dari DOB. 
5. Pemekaran daerah berdampak terhadap peningkatan daya tampung sekolah pada jenjang PAUD dan sekolah dasar. Sedangkan daya tampung sekolah pada jenjang pendidikan menengah cenderung menurun. Kondisi daya tampung sekolah di daerah induk lebih baik DOB pada setiap jenjang pendidikan.

6. Pemekaran daerah berdampak terhadap penurunan ketersediaan guru pada jenjang PAUD di daerah induk dan DOB dan peningkatan ketersediaan guru pada jenjang pendidikan dasar. Kondisi ketersediaan guru pada jenjang PAUD di daerah induk lebih baik sedangkan ketersediaan guru pada jenjang pendidikan dasar cenderung sama. Sedangkan pada jenjang pendidikan menengah, ketersediaan guru di daerah induk mengalami penurunan, tetapi di DOB mengalami peningkatan, sehingga ketersediaan guru di daerah DOB lebih baik.

7. Pemekaran daerah berdampak terhadap penurunan ketersediaan fasilitas kesehatan di daerah induk, dan peningkatan ketersediaan fasilitas kesehatan di DOB.

8. Pemekaran daerah berdampak terhadap peningkatan ketersediaan tenaga kesehatan di daerah induk dan DOB. Kondisi ketersediaan tenaga kesehatan di daerah induk dan DOB cenderung sama.

9. Pemekaran daerah berdanpak terhadap peningkatan proporsi jalan dalam kondisi baik di daerah induk dan DOB. Kondisi proporsi jalan dalam kondisi baik di DOB lebih baik dari daerah induk.

\section{DAFTAR PUSTAKA}

Arianti, N.N. \& Indra, C. 2014. Kajian Dampak Pemekaran Wilayah Terhadap Kinerja Ekonomi Daerah Pesisir Di Provinsi Bengkulu. Jurnal Agrisep, Volume 14, Nomor 2, Hal. 159-176.

Bappenas. 2005. Laporan Kajian Kebijakan Perencanaan Tenaga Kesehatan. Direktorat Jenderal Kesehatan dan Gizi Masyarakat Deputi Bidang Sumber Daya Manusia dan Kebudayaan, Jakarta.

Bappenas. 2008. Studi Evaluasi Dampak Pemekaran Daerah. Laporan Penelitian. Building and Reinventing Decentralised Governance (BRIDGE), Jakarta.

Bappenas. 2008 Studi Evaluasi (Impact) Penataan Daerah Otonomi Baru. Ringkasan Eksekutif. Direktorat Otonomi Daerah Deputi Bidang Pengembangan Regional dan Otonomi Daerah, Jakarta

Furry, R. 2013. Evaluasi Dampak Pemekaran Daerah Terhadap Kinerja Ekonomi dan Kinerja Pelayanan Publik di Kota Serang. Diponegoro Jurnal of Economics, Volume 2, Nomor 3, Hal. 1-13.

Hidayat, P., Pratomo, W.A \& Harjito, D.A. (2007). Analisis Kinerja Keuangan Kabupaten/Kota Pemekaran di Sumatera Utara. Jurnal Ekonomi Pembangunan: Kajian Ekonomi Negara Berkembang, Volume 12, Nomor 3, Hal. 213-222.

Rahayu, S., I. Wahyudi, Yudi, 2009. Analisis Kinerja Anggaran Keuangan Daerah Pemerintah Kota Jambi Dilihat Dari Perspektif Akuntabilitas. Jurnal Penelitian Universitas Jambi Seri Humaniora, Volume 2, Nomor 2, Hal. 25-30.

Soleh, A., Putra, I. E., \& Rahayu, Y. 2017. Analisis Kinerja Aparatur Dan Pelayanan Publik Sebagai Dasar Menuju Reformasi Birokrasi Yang Ideal. Jurnal Development, 5(2), 110-124.

Susanti, 2014. Dampak Pemekaran Wilayah Terhadap Kesejahteraan di Kabupaten Lampung Utara. Jurnal Ekonomi Pembangunan, Volume 3, Nomor 2, Hal. 249-268.

Yani, A., 2010. Kebutuhan Distribusi Guru Melalui Participatory Management Pada Era Otonomi Daerah. Jurnal Manajerial, Volume 9, Nomor 17, Hal. 47-54. 